\title{
A História das Famílias: o Trabalho com Narrativas Repletas de Significados e Interpretações na Formação Interprofissional de Enfermeiros e Médicos
}

\author{
Cyrino, Eliana Goldfarb; Romanholi, Renata Maria Zanardo; Roberto, Ana Paula \\ Costa
}

Depto de Saude Pública/Fmb/Unesp — ecyrino@fmb.unesp.br

Introdução:Objetivando-se maior aproximação do campo das humanidades na formação de profissionais de saúde, desenvolve-se, em universidade pública brasileira, desde 2006, disciplina interprofissional com participação anual de 120 estudantes de enfermagem e medicina, na atenção básica, nos 3 primeiros anos das graduações. Participam entre 12 a 14 alunos e um professor, por grupo. Cada estudante acompanha, na comunidade, uma família, construindo narrativas como estratégia educacional,em movimento que valoriza a voz singular do sujeito sobre a saúde e o adoecer. Destaca-se o trabalho com genograma, utilizado para compreensão de processos familiares, dinâmica de nascimentos, mortes, número de filhos, doenças, uniões e outros. Objetivo:Descrever o uso do genograma para reflexão e ação que promova aproximação do estudante com:sua história familiar; histórias das famílias das comunidades e; compreensão de que não existe um único modelo de família. Métodos: Pesquisa exploratória, na modalidade pesquisaação, social e educacional, realizada em estreita associação com ação de transformação da realidade. Participaram do estudo estudantes do segundo ano de graduação de medicina e enfermagem, entre 2011 e 2012. a partir da discussão sobre conceito de família, leitura de textos, vídeos, cada aluno:estudou o genograma de sua família, a saúde e processos de adoecimento; socializou com o grupo de estudantes e professor suas histórias e; realizou estudo do genograma de cada família acompanhada desde o primeiro ano da graduação. Resultados:A partir das narrativas orais, escritas e da construção gráfica dos genogramas das histórias familiares dos estudantes e de cada família da comunidade, com orientação,foi possível visualizar relações intra e extrafamiliares das famílias dos estudantes e das famílias acompanhadas na comunidade. Foram expressas opções de mudanças nas famílias, identificando-se características comuns e singulares. ao aluno que entrevistou sua própria família e uma família diferente da sua, o processo trouxe revelações que possibilitaram abertura para compreender o sofrimento, o significado do processo saúde-doença, a necessidade de ampliar a autonomia do sujeitos frente ao cuidado e reflexão sobre estratégias de produção de saúde que considerem a realidade do outro e sua relação com serviços de saúde.Também se identificou o encantamento com produções de qualidade literária compartilhadas entre todos. Conclusões:Na perspectiva pedagógica e assistencial, ao construir narrativas, o aluno se comunica com um outro diferente dele, reflete a respeito de questões que a família apresenta sobre seu modo de lidar com problemas de saúde. Apesar do poder objetivador instituído no contexto da formação destes profissionais e do modelo de atenção que imprime ao paciente submissão, esta vivência identifica-se como possibilidade de aprendizagem na graduação,que amplia a visão dos profissionais sobre o cuidado ao sujeito no contexto de cada existência. (Capes24/2010)

Cyrino, Eliana Goldfarb; Romanholi, Renata Maria Zanardo; Roberto, Ana Paula Costa. A História das Famílias: o Trabalho com Narrativas Repletas de Significados e Interpretações na Formação Interprofissional de Enfermeiros e Médicos. In: Anais do Congresso Internacional de Humanidades \& Humanização em Saúde [= Blucher Medical Proceedings, num.2, vol.1]. São Paulo: Editora Blucher, 2014. ISSN 2357-7282 DOI 10.5151/medpro-cihhs-10410 